\title{
FIELDWORK RESULTS OF WADER RESEARCH STATIONS WORKING IN POLAND IN 2002-2003
}

\author{
Mateusz Ściborski, Włodzimierz Meissner, Robert Krupa, Radosław Włodarczyk, \\ Krzysztof Kaczmarek, Rafał Bargiel, Adam Wojciechowski, \\ Aleksandra Raniczkowska, Radosław Kozik and Juliusz Pietrasik
}

Ściborski M., Meissner W., Krupa R., Włodarczyk R., Kaczmarek K., Bargiel R., Wojciechowski A., Raniczkowska A., Kozik R., Pietrasik J. 2005. Fieldwork results of wader research stations working in Poland in 2002-2003. Ring 27, 1: 93-99.

M. Ściborski, W. Meissner, Dept. of Vertebrate Zoology and Ecology, University of Gdańsk, Legionów 9, PL-80-441 Gdańsk, Poland, E-mail: mateo76@tlen.pl; R. Krupa, Dept. of Zoology, Warmia and Masuria University, Oczapowskiego 5, PL-10-957 Olsztyn, Poland, E-mail: krupi@op.pl; R. Włodarczyk, K. Kaczmarek, R. Bargiel, Dept. of Teaching Biology and Biodiversity Studies, University of Łódź, Banacha 1/3, PL-90-237 Łódź, Poland, E-mail: wradek@biol.uni.lodz.pl; A. Wojciechowski, A. Raniczkowska, Daniecka 2/3, 46-040 Ozimek, Poland; R. Kozik, Students' Scientific Circle of Ornithologists, Dept. of Biology, University of Podlasie, Prusa 12, PL-08-110 Siedlce, Poland, E-mail: kozirad@wp.pl; J. Pietrasik, Stary Radziejów 41, PL-88-200 Radziejów, Poland

In years 2002-2003 there were 7 active wader research stations working in Poland. One of them conducted only counts, others concentrated on ringing. Their localisations are shown in Figure 1. The characteristic of each station is described below.

\section{The Reda Mouth (RM)}

The station was organised by the Waterbird Research Group "Kuling" and University of Gdańsk. Among reported seasons it worked only in autumn 2002 (14-26 September). The description of the study area is placed elsewhere (Meissner and Remisiewicz 1998). This was the last season of fieldwork in this area, aimed mainly at collecting data on ecophysiology of fattening in Dunlin (Calidris alpina).

\section{Nisko (NI)}

The station of the WRG "Kuling" was organised with the support of Gdańsk University and University of Warmia and Masuria. It was located in WarmianMasurian Voivodship, near town of Reszel. Wader ringing was conducted in both years during spring and autumn migration. Birds were caught in mist-nets and walk-in traps, on shores of Lake Pleśno ( $c a 340$ ha) and by the River Sajna, in 


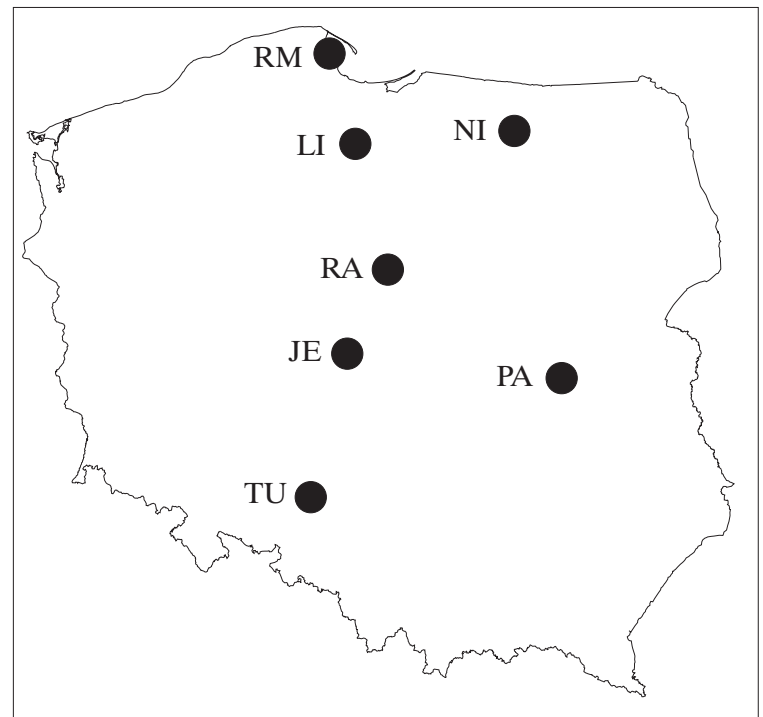

Fig. 1. Localities of research stations: RM - the Reda Mouth, NI - Nisko, LI - Lisewo, RA - Lake Rakutowskie, JE - Jeziorsko, TU - Turawa, PA - Pawłowice.

a temporarily flooded wetland ( $c a 50$ ha), densely covered by mosaic of reedbeds, rushes and aquatic plants. More about this place can be found in Meissner et al. (2002). Terms of fieldwork were: 28 April - 16 May and 25 July - 3 September 2002; 26 April - 16 May and 4 July - 23 August 2003.

\section{Lisewo (LI)}

A new station of the WRG "Kuling" was organised in cooperation with "Cormorant Group" from Warmia and Masuria University. It was placed on the right bank of the Vistula, vis-a-vis Tczew (Pomeranian Voivodship). The fieldwork was conducted in periods: 25 July - 20 August 2002 and 1 July - 15 September 2003. Main research topics were: migration strategy of the Common Sandpiper (Actitis hypoleu$\cos$ ) and post-breeding ecology of wagtails (Motacilla flava and M. alba). Waders were caught during the day in up to 15 walk-in traps, placed on rocky spurs and sandy islets emerging during low water, and also on small, ephemeral water bodies on a grazed meadow. Moreover, at nights mist-nets with tape luring were used. Additionally, all waders were counted twice a day.

\section{Lake Rakutowskie (RA)}

The fieldwork was conducted in August 2002. Ringing site was localised in the "Lake Rakutowskie" nature reserve (Kuyavian-Pomeranian Voivodship, 20 km SE from Włocławek), which covers area of 414 ha ( $c a 180$ ha of open water). A wide belt of vegetation around the lake comprises mostly reeds, rushes, and willows. Birds were caught in 10 walk-in traps. 
Jeziorsko (JE)

The station of the University of Łódź was situated by the water reservoir on the River Warta (Łódź Voivodship). The study area was described previously by Bargiel and Włodarczyk (1998). Birds were trapped in 28 walk-in traps, and in 2002 additionally in 3 mist-nets.

\section{Turawa (TU)}

The ringing station was placed by the Turawa reservoir $(\max .7 .5 \times 3.2 \mathrm{~km})$ on the River Mała Panew, $20 \mathrm{~km}$ E from Opole (Opole Voivodship). During low water level its predominantly sandy bottom emerges, with some small muddy pools and lagoons. In years 2002 and 2003 ringing activity was conducted in periods 5 July 20 August and 6 July - 20 August, respectively. Forty walk-in traps were used.

\section{Pawłowice (PA)}

The station of the Academy of Siedlce was located by the Vistula, $20 \mathrm{~km} \mathrm{~N}$ from Dęblin (Masovian Voivodship). In this place, the river creates sandy islets and lagoons, where waders can rest and forage. Year 2003 was the first season of the fieldwork, lasting from 1 to 29 August. Everyday 3 counts of waders were conducted along the riverbank. It is planned to establish ringing station there in the next year.

In both seasons most numerous species caught in Poland were inland migrating waders, i.e. Wood Sandpiper (Tringa glareola), Snipe (Gallinago gallinago), Ruff (Philomachus pugnax) and Common Sandpiper (Table 1 and 2). Additionally, in 2002 Dunlin was the commonest wader on the coast, at the Reda Mouth ringing site. In previous years, when catching of waders was focused on the Baltic coast (with ringing stations in the Vistula Mouth and by the Puck Bay), most numerously caught species were those linked more closely to marine habitats, i.e. Dunlin, Little Stint (Calidris minuta), Curlew Sandpiper (Calidris ferruginea), Knot (Calidris canutus). Also the species rarely recorded inland were more frequent: Grey Plover (Pluvialis squatarola), Turnstone (Arenaria interpres), Bar-tailed Godwit (Limosa lapponica) - cf. Gromadzka and Zieliński (2002), Meissner et al. (2002).

Present knowledge on inland migration of waders through Poland is rather poor. Results of regular counts were published for some places (Dyrcz 1981, Lontkowski et al. 1988, Kuźniak and Lorek 1993, Stawarczyk et al. 1996, Mitrus et al. 1998a, Polakowski and Juniewicz 1998, Wiehle 1999, Kruszyk and Zbroński 2002). Also biometric analyses on Wood Sandpiper and Common Sandpiper migrating in autumn in the Bug valley (Mitrus et al. 1998b, Mitrus et al. 1998c) were presented. The intensification of research gives a chance to fulfill the knowledge on inland wader migration in this part of Europe. 
Table 1

Numbers of birds ringed in Poland in 2002 at the six wader ringing stations. Abbreviations as in the text and in Figure 1.

\begin{tabular}{|c|c|c|c|c|c|c|c|c|}
\hline & Spring & & & & $\mathrm{mn}$ & & & Total \\
\hline & NI & NI & $\mathrm{RM}$ & $\mathrm{LI}$ & TU & $\mathrm{JE}$ & RA & \\
\hline Actitis hypoleucos & 1 & 34 & 3 & 88 & 209 & 163 & 3 & 501 \\
\hline Arenaria interpres & - & 2 & - & 2 & - & - & - & 4 \\
\hline Calidris alba & - & 1 & 1 & - & - & - & - & 2 \\
\hline Calidris alpina & 5 & 14 & 233 & 16 & 1 & 11 & 8 & 288 \\
\hline Calidris canutus & - & 3 & 3 & - & - & - & - & 6 \\
\hline Calidris ferruginea & - & 2 & 4 & 4 & - & 3 & 6 & 19 \\
\hline Calidris minuta & - & 1 & 7 & 5 & 2 & - & 8 & 23 \\
\hline Calidris temminckii & 2 & 12 & - & 27 & 20 & 3 & 3 & 67 \\
\hline Charadrius dubius & 2 & 15 & - & 17 & 60 & 20 & 5 & 119 \\
\hline Charadrius hiaticula & - & 2 & 6 & 7 & - & 6 & 5 & 26 \\
\hline Gallinago gallinago & - & 224 & 8 & 14 & 190 & 263 & 27 & 726 \\
\hline Gallinago media & - & 2 & - & - & - & - & - & 2 \\
\hline Limicola falcinellus & - & 1 & - & 7 & 1 & 1 & - & 10 \\
\hline Limosa lapponica & - & - & 27 & - & - & - & - & 27 \\
\hline Phalaropus lobatus & - & 1 & - & - & - & 1 & - & 2 \\
\hline Philomachus pugnax & 46 & 48 & 2 & 61 & 10 & 13 & 5 & 185 \\
\hline Pluvialis squatarola & - & - & 3 & - & - & - & - & 3 \\
\hline Tringa erythropus & 1 & 2 & - & - & 4 & 3 & - & 10 \\
\hline Tringa glareola & 198 & 174 & - & 24 & 459 & 678 & 48 & 1581 \\
\hline Tringa nebularia & - & 5 & - & - & - & 1 & 1 & 7 \\
\hline Tringa ochropus & - & 3 & - & 2 & 23 & 3 & - & 31 \\
\hline Tringa stagnatilis & - & - & - & - & - & 2 & - & 2 \\
\hline Tringa totanus & 4 & 4 & 1 & 3 & 3 & 4 & - & 19 \\
\hline Vanellus vanellus & 3 & 3 & - & 1 & 10 & 11 & - & 28 \\
\hline Xenus cinereus & - & - & - & - & - & 1 & - & 1 \\
\hline Total & 262 & 553 & 298 & 278 & 992 & 1187 & 119 & 3689 \\
\hline
\end{tabular}


Table 2

Numbers of birds ringed in Poland in 2003 at four wader ringing stations. Abbreviations as in Table 1.

\begin{tabular}{|c|c|c|c|c|c|c|}
\hline & \multirow{2}{*}{$\begin{array}{c}\text { Spring } \\
\text { NI }\end{array}$} & \multicolumn{4}{|c|}{ Autumn } & \multirow[t]{2}{*}{ Tota } \\
\hline & & NI & LI & $\mathrm{TU}$ & $\mathrm{JE}$ & \\
\hline Actitis hypoleucos & - & 6 & 60 & 103 & 44 & 213 \\
\hline Arenaria interpres & - & - & 14 & - & - & 14 \\
\hline Calidris alpina & - & - & 72 & 22 & - & 94 \\
\hline Calidris canutus & - & - & 16 & - & - & 16 \\
\hline Calidris ferruginea & - & - & 82 & 2 & - & 84 \\
\hline Calidris minuta & - & - & 20 & 11 & - & 31 \\
\hline Calidris temminckii & 10 & - & 32 & 10 & - & 52 \\
\hline Charadrius dubius & - & 4 & 32 & 43 & 7 & 86 \\
\hline Charadrius hiaticula & - & - & 86 & 1 & - & 87 \\
\hline Gallinago gallinago & 3 & 144 & 37 & 86 & 243 & 513 \\
\hline Gallinago media & - & - & - & 1 & - & 1 \\
\hline Limicola falcinellus & - & 1 & 1 & - & - & 2 \\
\hline Numenius arquata & - & - & 8 & - & 1 & 9 \\
\hline Philomachus pugnax & 61 & 11 & 142 & 10 & 80 & 304 \\
\hline Pluvialis apricaria & - & - & 1 & - & - & 1 \\
\hline Tringa erythropus & - & - & 1 & - & 4 & 5 \\
\hline Tringa glareola & 385 & 55 & 34 & 400 & 1137 & 2011 \\
\hline Tringa nebularia & - & - & - & 1 & 2 & 3 \\
\hline Tringa ochropus & - & 9 & 2 & 12 & 19 & 42 \\
\hline Tringa totanus & 1 & 2 & 26 & 3 & 17 & 49 \\
\hline Vanellus vanellus & 4 & 2 & 1 & 4 & 34 & 45 \\
\hline Total & 464 & 234 & 667 & 709 & 1588 & 3662 \\
\hline
\end{tabular}

In the species composition in Pawłowice, the dominant with almost half of all waders counted is the Lapwing (Vanellus vanellus) - see Table 3. It is in agreement with the results from autumn counts in southwestern Poland (Dyrcz 1981, Stawarczyk et al. 1996, Kruszyk and Zbroński 2002). Also in spring, in wide, open areas of river valleys, Lapwings are most numerous waders (Kube 1988, Wójcik et al. 1999). 
Table 3

Total number of birds recorded in all counts in Pawłowice in 2003

\begin{tabular}{|c|c|c|}
\hline & Total no. of observed birds & Dominance $(\%)$ \\
\hline Actitis hypoleucos & 609 & 13.9 \\
\hline Arenaria interpres & 4 & 0.1 \\
\hline Calidris alba & 1 & 0.0 \\
\hline Calidris alpina & 21 & 0.5 \\
\hline Calidris ferruginea & 10 & 0.2 \\
\hline Calidris temminckii & 65 & 1.5 \\
\hline Charadrius dubius & 102 & 2.3 \\
\hline Charadrius hiaticula & 165 & 3.8 \\
\hline Gallinago gallinago & 235 & 5.4 \\
\hline Limosa lapponica & 1 & 0.0 \\
\hline Limosa limosa & 2 & 0.0 \\
\hline Numenius arquata & 116 & 2.7 \\
\hline Philomachus pugnax & 36 & 0.8 \\
\hline Pluvialis apricaria & 1 & 0.0 \\
\hline Pluvialis squatarola & 1 & 0.0 \\
\hline Tringa erythropus & 10 & 0.2 \\
\hline Tringa glareola & 440 & 10.1 \\
\hline Tringa nebularia & 399 & 9.1 \\
\hline Tringa ochropus & 38 & 0.9 \\
\hline Tringa totanus & 15 & 0.3 \\
\hline Vanellus vanellus & 2100 & 48.0 \\
\hline Total & 4371 & 100.0 \\
\hline
\end{tabular}

\section{REFERENCES}

Dyrcz A. 1981. Birds of Otmuchowski Reservoir. Acta zool. cracov. 25: 69-102.

Bargiel R., Włodarczyk R. 1998. Catching waders at the Jeziorsko reservoir (western Poland). Ring 20, 1-2: 77-82.

Gromadzka J., Zieliński P. 2002. Wader ringing at the Vistula mouth in years 1999-2000. Ring 24, 1: $127-130$.

Kruszyk R., Zbroński R. 2002. Migration of waders (Charadrii) at the sediment-ponds and floods of coalmines in Jastrzębie Zdrój. Ring 24, 1: 105-119.

Kube J. 1988. Zum Limikolendurchzug im Unteren Odertal (1976-1986). Beitr. Vogelkd. 34: 177-193.

Kuźniak S., Lorek G. 1993. [Birds of the Wonieść reservoir and adjacent grounds]. Prace Zakł. Biol. i Ekol. Ptaków UAM. 2. Poznań. (In Polish). 
Lontkowski J., Okulewicz J., Drazny T. 1988. [Birds (Non-Passeriformes) of irrigational fields and adjacent grounds in NW part of Wroclaw]. Ptaki Śląska 6: 43-96. (In Polish).

Meissner W., Remisiewicz R. 1998. Wader Studies of the Waterbird Research Group "KULING" in 1983-1998. Ring 20, 1-2: 21-33.

Meissner W., Ściborski M., Włodarczak A. 2002. Wader studies of the Waterbird Research Group "Kuling" in 1999-2001. Ring 24, 1: 131-135.

Mitrus C., Kuczborski R., Słupek J. 1998a. Report on ringing and observations of waders at the Bug river (central-eastern Poland) in 1986-1990. Ring 20, 1-2: 73-76.

Mitrus C., Kuczborski R., Słupek J. 1998b. The autumn passage of the Wood Sandpiper (Tringa glareola) in the Bug valley - dynamics and biometry. Ring 20,1-2: 107-116.

Mitrus C., Kuczborski R., Słupek J. 1998c. Autumn passage of the Common Sandpiper Actitis hypoleucos in the Bug River valley - dynamics and biometry. Not. Orn. 39: 13-25.

Polakowski M., Juniewicz M. 1998. Autumn migration of waders at the Sewage Treatment Plant in Fasty near Biatystok (eastern Poland). Ring 20, 1-2: 59-68.

Stawarczyk T., Grabiński W., Karnaś A. 1996. [Migration of Charadriiformes on Nyski and Turawa Reservoir in years 1976-94]. Ptaki Śląska 11: 39-80.

Wiehle D. 1999. Migration of waders (Charadrii) in the fishponds in Spytkowice in years 1995-1999. Ring 21, 2: 91-105.

Wójcik C., Rydzkowski P., Ściborski M. 1999. The spring migration of waders Charadrii in the lower Vistula valley. Ring 21, 2: 79-90. 